\title{
PENAMBAHAN ENZIM FITASE PADA RANSUM DENGAN LEVEL PROTEIN BERBEDA TERHADAP EFISIENSI PROTEIN AYAM BROILER
}

(Phytase Enzymes Addition in The Ration with Different Protein Level On Protein Efficiency of Broiler Chickens)

\author{
Apriliyana, K. T' ${ }^{1}$, Suprijatna E. ${ }^{2}$ dan Atmomarsono, $\mathbf{U}^{3}$ \\ 1) Mahasiswa Pasca Sarjana Fakultas Peternakan dan Pertanian Universitas Diponegoro \\ Kampus drh. Soejono Koesoemowardojo Tembalang Semarang 50275 \\ E-mail : teeka.tries@gmail.com \\ ${ }^{2,3)}$ Fakultas Peternakan dan Pertanian, Universitas Diponegoro \\ Kampus drh. R. Soejono Kusumowardojo Tembalang, Semarang 50275
}

Diterima : 15 Desember 2014 Disetujui : 25 September 2015

\begin{abstract}
The research was conducted to learn the effect of phytase enzymes addition in the ration with different protein level on protein efficiency broiler chickens. Material the research used were 128 broiler chickens at 8 days old initial body weight 108,14 $\pm 11,44 \mathrm{~g}$ (CV 10,58\%) housed in 16 pen for 6 weeks. Complete Random Design (RAL) involving 4 treatments with 4 repetitions were used in this study are TO (23\% protein ration), T1 (21\% protein ration +1000 FTU phytase enzymes), T2 (23\% protein ration +1000 FTU phytase enzymes), T3 (23\% protein ration $+1 \%$ bone meal). The data was analyzed using $F$ test to determine the effect of treatment, continued with Duncan's multiple range test with probability level at 5\% if any significant effect was found. Parameters research were protein consumption, ileal protein digestibility and protein efficiency ratio (PER). The results showed that the addition of phytase enzymes in the diet that there was significant effect $(P<0,05)$ on the protein consumption, ileal protein digestibility and protein efficiency ratio $(P E R)$. The conclusion of this research is the addition of phytase enzymes in the $21 \%$ protein ration results in protein efficiency have better than control ration, addition phytase in protein $23 \%$ of ration and addition mineral in protein $23 \%$ of ration.
\end{abstract}

Key words : phytase enzymes, protein level, protein efficiency, broiler chickens.

\section{ABSTRAK}

Penelitian ini bertujuan untuk mengkaji penggunaan enzim fitase dalam ransum pada taraf protein yang tepat untuk meningkatkan efisiensi penggunaan protein ayam broiler. Materi yang digunakan dalam penelitian adalah ayam broiler dengan bobot badan 108,14 \pm 11,44 g (CV 10,58\%) umur 1 minggu sebanyak 128 ekor (unsex) yang dipelihara dalam 16 unit kandang selama 6 minggu, masing-masing unit berisi 8 ekor ayam. Penambahan fitase dilakukan pada minggu kedua pemeliharaan. Rancangan percobaan yang digunakan adalah rancangan acak lengkap dengan 4 perlakuan dan 4 ulangan yaitu T0 (Ransum protein 23\%), T1 (Ransum protein 21\% + fitase $1000 \mathrm{FTU} / \mathrm{kg}$ ), T2 (Ransum protein 23\% + enzim fitase 1000 FTU/kg), T3 (Ransum protein 23\% + mineral 1\%). Data dianalisis ragam menggunakan uji $\mathrm{F}$ pada taraf 5\%, jika ada pengaruh perlakuan dilanjutkan dengan uji duncan untuk melihat 
perbedaan antar perlakuan. Parameter penelitian meliputi konsumsi protein, kecernaan protein ileal dan rasio efisienfi protein. Hasil penelitian perlakuan menunjukkan berpengaruh nyata $(\mathrm{P}<0,05)$ terhadap konsumsi protein, kecernaan protein ileal dan rasio efisiensi protein. Kesimpulan dari penelitian ini adalah ransum protein $21 \%$ yang ditambahkan fitase menunjukkan hasil efisiensi protein yang lebih baik dibandingkan ransum kontrol, ransum protein $23 \%$ yang ditambah fitase maupun ransum protein $23 \%$ yang ditambahkan mineral.

Kata kunci : fitase, level protein, efisiensi protein, broiler

\section{PENDAHULUAN}

Dewasa ini peternakan unggas berkembang pesat, salah satunya peternakan ayam broiler. Ransum unggas terutama terdiri dari tumbuhan yang berasal dari bijibijian, namun dalam pemanfaatannya pakan tersebut mengandung asam fitat yang tidak bisa dihidrolisis oleh saluran pencernaan. Asam fitat merupakan zat antinutrisi yang terdapat dalam kacang-kacangan yang dapat bervalensi dengan mineral $(\mathrm{Ca}, \mathrm{Mg}, \mathrm{Zn}, \mathrm{Fe})$ dan protein sehingga menyebabkan terjadinya gangguan kecernaan yang dapat menurunkan nilai gizi. Ketersediaan protein sebagai substrat dalam tubuh berhubungan erat dengan metabolisme protein khususnya proses deposisi protein yang menunjang pertumbuhan. Proses pertumbuhan melalui deposisi protein daging secara kimiawi ditunjang oleh beberapa faktor antara lain kalsium dalam bentuk ion dan aktivitas enzim protease yang disebut Calcium Activated Neutral Protease (CANP) dalam daging (Biehl et al., 1997). Terbentuknya senyawa fitat-mineral atau fitat-protein yang tidak larut dapat menyebabkan penurunan ketersediaan mineral dan nilai gizi protein pakan. Mineral-mineral dan protein yang membentuk komplek dengan fitat tersebut tidak dapat diserap oleh dinding usus bagi ternak (Kornegay et al., 1999). Aktivitas enzim protease dan tripsine dalam saluran pencernaan menjadi rendah dengan adanya protein yang terikat asam fitat (Caldwell, 1992). Ikatan kompleks fitat dan mineral yang tidak larut aktif sebagai penghambat kecernaan protein. Asam fitat menghambat penyerapan protein dan mineral saat pencernaan pakan, oleh karena itu upaya peningkatan efisiensi protein pakan dilakukan dengan beberapa cara, salah satunya dengan penggunaan enzim fitase.

Enzim fitase merupakan enzim yang dapat mengkatalisis reaksi hidrolisis asam fitat dan menghasilkan ortofosfat anorganik serta senyawa inositol fosfat yang lebih rendah. Enzim fitase dapat mengatasi efek negatif dari asam fitat terhadap performan ternak. Penggunaan enzim sebagai suplementasi dalam ransum dapat menguntungkan secara ekonomi bila dapat meningkatkan secara nyata efisiensi ransum dan menekan harga ransum. Enzim fitase yang diproduksi oleh fungus Aspergillus ficcum NRRL 3135 mempunyai aktivitas enzim fitase tertinggi, sehingga sangat cocok digunakan sebagai feed additive (Augspurger et al. 2003). Suplementasi enzim fitase Natuphos sebanyak 500 fitase total unit (FTU)/kg pada ransum ayam broiler yang mengandung P-tersedia rendah $(0.22 \%$ untuk umur 1 hari-3 minggu dan $0.14 \%$ untuk ayam umur 3-6 minggu), mampu memperbaiki performan dan meningkatkan penggunaan mineral $\mathrm{P}, \mathrm{Ca}, \mathrm{Mg}$ dan $\mathrm{Zn}$ (Viveros et al., 2002). Hasil penelitian Lan et al. (2002), menunjukkan bahwa efisiensi suplementasi fitase pada performan dan kecernaan nutrisi ayam broiler pada pakan rendah Non-Phospat Phospor (NPP) menghasilkan performan pertumbuhan yang lebih baik pada nilai kecernaan protein dan bahan kering, penggunaan $\mathrm{Ca}, \mathrm{P}$, dan $\mathrm{Cu}$, dan mineralisasi tulang dibandingkan dengan penambahan enzim fitase 250 FTU, 500 FTU dan 750 FTU. Unggas tidak dapat menghasilkan enzim fitase pemecah asam fitat sehingga perlu diberikan enzim fitase dalam pakan, hal ini bertujuan untuk meningkatkan penyerapan nutrisi protein dan mineral serta kecernaan bahan pakan. 
Sehingga, diharapkan akan meningkatkan efisiensi penggunaan protein ayam broiler.

Tujuan dari penelitian ini adalah mengkaji peningkatan efisiensi protein ayam broiler akibat penambahan fitase pada ransum taraf protein yang berbeda. Hasil penelitian ini bermanfaat untuk memberikan informasi bahwa penambahan enzim fitase pada level protein berbeda dalam ransum yang efisien untuk ayam broiler.

\section{MATERI DAN METODE}

Penelitian dilaksanakan di kandang Fakultas Peternakan dan Pertanian Universitas Diponegoro Semarang selama 6 minggu yaitu mulai bulan Desember 2013Januari 2014.

\section{Materi}

Materi yang digunakan adalah ayam broiler dengan bobot badan 108,14 $\mathrm{g} \pm 11,44$ g (CV 10,58\%) umur 1 minggu sebanyak 128 ekor, enzim fitase merk Natuphos $5000 \AA$, vaksin gumboro, vaksin NDIB dan ND Lasota. Komposisi dan kandungan nutrisi penyusun ransum terdapat pada Tabel 1 yang terdiri dari jagung kuning, bekatul, bungkil kedelai, PMM (Poultry Meat Meal), tepung ikan, tepung tulang steam. Ransum dalam bentuk mash. Untuk analisis protein ekskreta digunakan gelas ukur, pipet tetes, labu Kjeldahl, erlenmeyer, beker glass, alat destilasi, incubator, serta buret. Kandang perlakuan kecernaan menggunakan kandang cage sejumlah 16 buah cage.

Tabel 1. Bahan Pakan dan Kandungan Nutrisi Ransum Penelitian

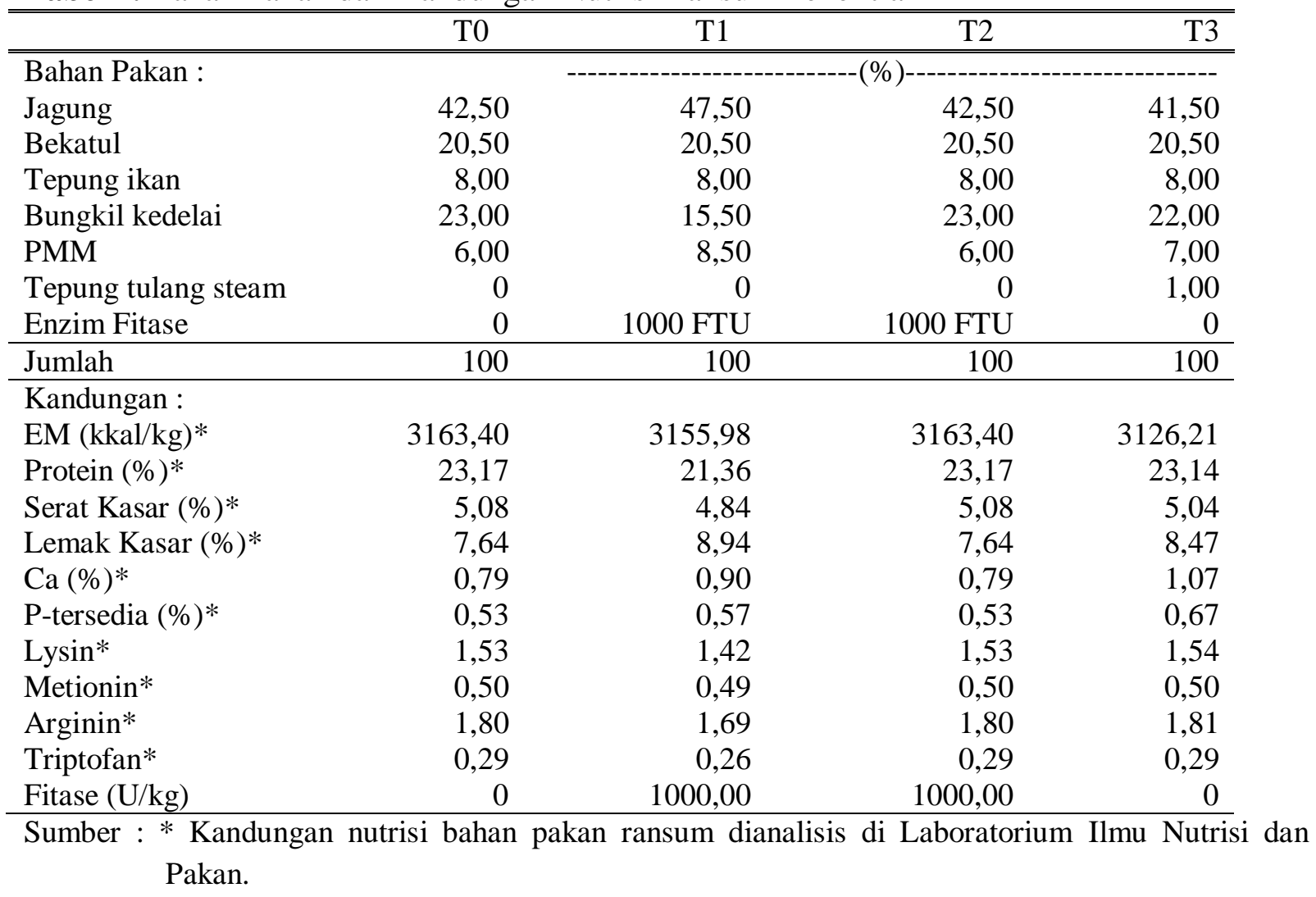




\section{Metode}

\section{Rancangan Penelitian}

Percobaan menggunakan Rancangan Acak Lengkap dengan 4 perlakuan dan 4 ulangan, setiap unit percobaan diisi 8 ekor DOC. Ransum perlakuan terdiri dari:

T0 : Ransum protein $23 \%$

T1 : Ransum protein $21 \%$ + enzim fitase $1000 \mathrm{FTU} / \mathrm{kg}$

T2 : Ransum protein $23 \%$ + enzim fitase $1000 \mathrm{FTU} / \mathrm{kg}$

$\mathrm{T} 3$ : Ransum protein $23 \%+$ tepung tulang $1 \%$

\section{Prosedur Penelitian}

Ransum dan air minum diberikan ad libitum. Ransum perlakuan dengan penambahan enzim fitase diberikan mulai hari ke-8 sampai hari ke-42. Setiap akhir minggu dilakukan penimbangan bobot badan untuk mengetahui pertambahan bobot badan. Pengambilan data konsumsi protein dilakukan setiap hari dengan menimbang jumlah konsumsi ransum dikalikan dengan kadar protein ransum. Untuk pengambilan data kecernaan protein diambil 1 ekor ayam kemudian ditempatkan pada kandang cage dan dipuasakan selama 24 jam namun air minum tersedia ad libitum. Ayam diberi pakan sebanyak $70 \mathrm{~g}$ per ekor dengan metode force feeding setelah pemuasaan selesai. Metode force feeding tidak dilakukan dengan memasukkan pakan langsung ke tembolok, namun dengan membentuk pakan menjadi bolus (gumpalan) lalu dimasukkan ke mulut ayam, pakan harus habis dalam waktu 1 - 2 jam, namun air minum tetap disediakan hingga saat penyembelihan. Empat jam setelah pakan habis dikonsumsi, ayam disembelih dan organ dalamnya dikeluarkan. Digesta diambil dari usus halus bagian ileum, yaitu $1 \mathrm{~cm}$ setelah Meckel's diverticulum hingga batas $1 \mathrm{~cm}$ sebelum ileo-ceca junction. Digesta diletakkan dalam nampan dan dijemur selama empat hari, setelah itu dianalisis kandungan proteinnya dengan metode mikro Kjehldahl di Laboratorium Ilmu Nutrisi dan Pakan

Fakultas Peternakan dan Pertanian Universitas Diponegoro.

Data diolah menggunakan sidik ragam dan apabila menunjukkan pengaruh nyata $(\mathrm{P}<0,05)$ akibat perlakuan dilanjutkan dengan uji Duncan untuk mengetahui perbedaan antar perlakuan.

\section{Parameter Penelitian}

Parameter penelitian yang diteliti adalah konsumsi protein, kecernaan protein ileal dan rasio efisiensi protein. Konsumsi protein dihitung setiap hari selama masa penelitian, sedangkan parameter kecernaan protein ileal diambil pada masa akhir penelitian saat ayam broiler umur 42 hari.

\section{HASIL DAN PEMBAHASAN}

Pengaruh penambahan enzim fitase pada ransum dengan level protein berbeda terhadap efisiensi ransum yang terdiri dari konsumsi protein, kecernaan protein ileal dan rasio efisiensi protein disajikan dalam Tabel 2. 
Tabel 2. Pengaruh Penambahan Enzim Fitase pada Level Protein Berbeda terhadap Efisiensi Ransum Ayam Broiler

\begin{tabular}{lcccc}
\hline \hline \multirow{2}{*}{ Parameter } & \multicolumn{4}{c}{ Perlakuan } \\
\cline { 2 - 5 } & T0 & T1 & T2 & T3 \\
\hline Konsumsi Protein (g/ekor/hari) & $12,47 \pm 1,85^{\mathrm{b}}$ & $13,67 \pm 1,62^{\mathrm{b}}$ & $15,12 \pm 2,01^{\mathrm{b}}$ & $17,99 \pm 1,28^{\mathrm{a}}$ \\
Kecernaan Protein Ileal (\%) & $40,79 \pm 2,02^{\mathrm{c}}$ & $39,82 \pm 0,28^{\mathrm{c}}$ & $43,55 \pm 1,33^{\mathrm{b}}$ & $64,62 \pm 1,30^{\mathrm{a}}$ \\
Rasio Efisiensi Protein (REP) & $1,37 \pm 0,14^{\mathrm{b}}$ & $1,66 \pm 0,13^{\mathrm{a}}$ & $1,54 \pm 0,11^{\mathrm{ab}}$ & $1,46 \pm 0,13^{\mathrm{ab}}$ \\
\hline
\end{tabular}

Keterangan : Superskrip berbeda pada baris yang sama menunjukkan perbedaan nyata $(\mathrm{P}<0,05)$

\section{Konsumsi Protein}

Pengaruh penambahan enzim fitase pada ransum dengan level protein berbeda pada ayam broiler berpengaruh nyata $(\mathrm{P}<0,05)$ terhadap konsumsi protein (g/ekor/hari) disajikan dalam Tabel 2. Berdasarkan uji Duncan, diperoleh bahwa konsumsi protein perlakuan T3 (protein 23\% + mineral $1 \%$ ) meningkat secara nyata dibandingkan perlakuan T0, T1 dan T2 yang disebabkan konsumsi ransum perlakuan berbeda nyata antar perlakuan. protein dipengaruhi oleh konsumsi ransum, sedangkan konsumsi ransum dipengaruhi oleh metabolisme zat-zat makanan dalam tubuh. Semakin baik metabolisme zat-zat makanan dalam tubuh maka akan berpengaruh juga nafsu makan dan konsumsi ransumnya. Perlakuan T3 (protein $23 \%+$ mineral $1 \%$ ) mengalami peningkatan ketersediaan fosfor bagi tubuh ternak akibat penambahan mineral. Menurut Trisiwi et al (2004), fosfor mempunyai peran dalam metabolisme karbohidrat. Penelitian ketersediaan fosfor dalam defluorionated fosfat dengan solubilitas fosfor yang berbeda oleh Coffey et al., (1994), secara nyata meningkatkan konsumsi ransum, pertambahan bobot badan, konversi ransum, kekuatan tulang tibia ayam broiler. Ahmed et al., (2004), menyatakan bahwa konsumsi ransum, konversi ransum, bobot badan ayam broiler meningkat akibat suplementasi fitase pada ransum berbasis tepung kedelai.
Menurut Wahju (2004), besarnya konsumsi ransum mencerminkan besarnya protein yang dikonsumsi. Konsumsi ransum yang tinggi, maka konsumsi protein juga semakin tinggi, begitu juga sebaliknya jika konsumsi ransum rendah maka konsumsi protein juga rendah.

Hasil penelitian ini menunjukkan besarnya konsumsi protein berkisar 12,4717,99\%. Wahju (2004) menyatakan bahwa, kebutuhan protein ayam broiler umur 6 minggu adalah 14,1-19,1\% dengan rata-rata sekitar 16,6\%. Berdasarkan hasil penelitian rata-rata konsumsi protein ayam broiler akibat penambahan fitase dalam ransum dengan level protein berbeda yaitu $14,81 \%$ sesuai dengan standar konsumsi protein yaitu 14,1-19,1\%. Hal tersebut dikarenakan fitase dapat memecah ikatan fitat dengan mineral dan protein sehingga ketersediaan protein dan mineral menjadi lebih baik. Augspurger et al. (2003), yang menyatakan bahwa enzim fitase aktif didalam saluran pencernaan unggas. Ikatan fitat dengan fosfor lepas akibat kerja enzim fitase sehingga meningkatkan ketersediaan mineral fosfor, protein dan energi.

\section{Kecernaan Protein Ileal}

Berdasarkan analisis ragam, perlakuan penambahan fitase pada ransum level protein berbeda memberikan pengaruh nyata $(\mathrm{P}<0,05)$ terhadap kecernaan protein ileal yang disajikan dalam Tabel 2. Uji duncan 
menunjukkan T3 meningkat secara nyata akibat penambahan mineral $1 \%$ dibandingkan dengan perlakuan T0, T1 dan T2. Penambahan fitase pada ransum protein rendah (T1) berbeda dengan ransum protein tinggi yang ditambahkan mineral 1\% (T3) dan penambahan fitase pada protein tinggi (T2), tetapi tidak berbeda dengan ransum kontrol (T0) akibat konsumsi protein yang berbeda antar perlakuan. Konsumsi nutrisi yang meningkat diiikuti dengan kecernaan yang tinggi menyebabkan jumlah nutrisi yang tercerna dan terserap semakin banyak. Konsumsi ransum dan konsumsi protein ransum T0 dan ransum T2 tidak berbeda, tetapi pada retensi protein ransum T2 (protein 23\%+fitase $1000 \quad$ FTU $/ \mathrm{kg}$ ) menunjukkan hasil yang lebih baik dibandingkan ransum kontrol. Penambahan mineral $1 \%$ nyata lebih baik meningkatkan kecernaan protein ileal dibandingkan ransum protein $23 \%$ yang ditambahkan fitase akibat ketersediaan mineral yang lebih baik pada ransum T3 sehingga nutrisi yang terserap dalam usus juga meningkat. Mirnawati et al. (2013), menyatakan kecernaan protein kasar tergantung pada kandungan protein di dalam ransum. Ransum yang kandungan proteinnya rendah, umumnya mempunyai kecernaan yang rendah pula dan sebaliknya. Tinggi rendahnya kecernaan protein tergantung pada kandungan protein ransum dan banyaknya protein yang masuk dalam saluran pencernaan. Menurut Wahju (2004), kecernaan dipengaruhi komposisi ransum, jumlah pemberian, jenis ternak, penyajian pakan.

Berdasarkan uji duncan kecernaan protein ileal $\mathrm{T} 3$ meningkat secara nyata dibandingkan T0, T1 dan T2. Penambahan fitase pada ransum protein tinggi (T2) berbeda dengan ransum protein tinggi yang ditambahkan mineral 1\% (T3), penambahan fitase pada protein tinggi (T2) dan ransum kontrol (T0). Perlakuan ransum T0 dan T1 tidak berbeda, hal tersebut merupakan akibat dari penambahan fitase pada ransum protein $21 \%$ sehingga dapat menyamai kecernaan protein ileal ransum kontrol protein 23\% yang menunjukkan bahwa ketersediaan protein ransum yang ditambahkan fitase meningkat. Enzim fitase berpengaruh positif pada ketersediaan protein, dengan adanya hidrolisis asam fitat oleh enzim dan melepaskan ikatan fitat-protein-asam amino. Sesuai Biehl dan Baker (1997) yang menyatakan bahwa fitase memegang peran kecil, akan tetapi signifikan berpengaruh positif terhadap ketersediaan metionin, treonin, lisin dan valin. Penambahan fitase pada ransum protein rendah (T1) tidak berbeda dengan ransum kontrol protein 23\%(T0). Hal tersebut dikarenakan fitase dapat melepaskan ikatan asam fitat dan protein sehingga ketersediaan protein meningkat dan kecernaan menjadi lebih baik pula. Hasil penelitian Kies et al. (2001), menunjukkan bahwa daya cerna protein kasar secara signifikan meningkat pada ayam broiler yang diberikan suplementasi fitase mikroba. Hasil penelitian Lan et al (2001), suplementasi enzim fitase 500 dan 1.000 FTU/kg pakan secara signifikan meningkatkan kecernaan protein.

\section{Rasio Efisiensi Protein}

Penambahan enzim fitase pada level protein yang berbeda dalam ransum broiler memberikan pengaruh berbeda nyata $(\mathrm{P}<0,05)$ terhadap rasio efisiensi protein yang terdapat pada Tabel 2. Hasil analisis menunjukkan penambahan penambahan enzim fitase pada level protein yang berbeda dalam ransum broiler memberikan pengaruh berbeda nyata $(\mathrm{P}<0,05)$ terhadap rasio efisiensi protein. Hal ini disebabkan karena konsumsi protein dan pertambahan bobot 
badan yang berbeda nyata antar perlakuan. Menurut Wahju (2004), diperoleh dengan cara pertambahan bobot badan (g) dibagi konsumsi protein (g) untuk mengetahui kualitas protein. Menurut Kompiang et al. (2001), penurunan imbangan efisiensi protein merupakan indikator bahwa konsumsi protein melebihi kebutuhan.

Hasil penelitian menunjukkan T1 (protein 21\% + fitase $1000 \mathrm{FTU} / \mathrm{kg}$ ) berbeda dengan T0, tetapi T2 dan T3 tidak berbeda nyata dengan $\mathrm{T} 0$ dan $\mathrm{T} 1$ yang menandakan bahwa ransum dengan protein lebih rendah memiliki efisiensi protein yang baik dengan ditambahkan fitase dalam ransum dibandingkan dengan ransum kontrol (protein 23\%). Penambahan fitase dalam ransum menyebabkan ikatan asam fitat dengan protein dan mineral terlepas sehingga protein yang dicerna ketersediaannya meningkat sehingga bioavability protein dalam pakan meningkat. Onyango et al. (2004) menyatakan bahwa suplementasi enzim fitase sebanyak 1000 FTU/kg ke dalam ransum dapat meningkatkan pertambahan bobot badan dan efisiensi ransum. Yusriani (2011) bahwa efisiensi protein secara nyata lebih baik pada perlakuan pakan dengan konsentrasi protein dan energi rendah. Saima et al. (2010) melaporkan bahwa ransum ayam broiler yang diturunkan proteinnya menjadi lebih efisien dengan koreksi asam-asam amino esensial.

\section{KESIMPULAN DAN SARAN}

\section{Kesimpulan}

Berdasarkan hasil penelitian dapat disimpulkan bahwa penambahan fitase dalam ransum broiler umur 6 minggu yang berbeda taraf proteinnya berpengaruh nyata pada konsumsi protein, kecernaan protein ileal dan rasio efisiensi protein, namun tidak berpengaruh terhadap penggunaan protein netto (PPN). Penambahan fitase hanya akan meningkatkan rasio efisiensi meningkat pada ransum protein $21 \%$. Penambahan mineral berpengaruh meningkatkan konsumsi protein, kecernaan ileal dan rasio efisiensi protein (Lim, et al, 2003).

\section{Saran}

Berdasarkan hasil penelitian disarankan bahwa sebaiknya pada ransum dengan protein $21 \%$ ditambahkan fitase untuk meningkatkan efisiensi pakan ayam broiler.

\section{DAFTAR PUSTAKA}

Ahmed, F., M. S. Rahman, S. U. Ahmed and M. Y. Miah. 2004. Performance of broiler on phytase supplemented soybean meal based diet. J. Poultry Sci. 3 (4) :266-271.

Augspurger. N. R., D. M. Webel., X.G. Lei and D. H. Baker. 2003. Efficacy of an E. Coli phytase expressed in yeast for releasing phytate-bound phosphorus in young chick and pigs. J. Anim. Sci. 81 : 474-483.

Biehl, R. R., and D. H. Baker. 1997a. Microbial phytase improves amino acid utilization in young chicks fed diets based on soybean meal but not diets based on peanut meal. Poult. Sci. 76 : 355-360.

Caldwell, R.A. 1992. Effect of calcium and phytic acid on the activation of trypsinogen and the stability of trypsin. J. Agric. A Food Chem. 40 : 406-413. 
Coffey, R. D., K. W. Mooney, G. L. Cromwell and D. K. Aaron. 1994. Biological availability of phosphorus in defluorinated phosphates with different phosphorus solubilities in neutral ammonium citrate for chicks and pigs. J. Anim. Sci. 72 : 2653-2660

de Carvalho, F.B., J.H. Stringhini, M.S. Matos, R.M.J. Filho, M.B. Cafe, N.S.M. Leandro, and M.A. Andrade. 2012. Performance and nitrogen balance of laying hens fed increasing levels of digestible lysine and arginine. R. Bras. Zootec. 41 (10) : $2183-2188$.

Kompiang, I.P., Supriyati, M.H. Togatorop, dan S.N. Jarmani. 2001. Kinerja ayam kampung dengan pemberian pakan secara memilih dengan bebas. Jurnal Ilmu Ternak dan Veteriner 6 (2): 94 - 99.

Kornegay E.T., Z. Yi, and D.H Baker. 1999. Effect of supplemental natuphos phytase on trace mineral availability for poultry. Di dalam: Coelho MB, Kornegay ET. Phytase in Animal Nutrition and Waste Management. A BASF Reference Manual. Ed ke-2. BASF Corporation. Hlm 497 - 506.

Lan G.Q., N. Abdullah, S. Jalaludin and Y.W. Ho. 2002. Efficacy of supplementation of a phytase producing bacterial culture on the performance and nutrisit use of broiler chickens fed corn-soybean meal diets. Poult. Sci. 81:1522-1532.

Lim, H.S., H., Namkung and I.K., Paik. 2003. Effects of phytase supplementation on the performance, egg qua lity, and phosphorus excretion of laying hens fed differet levels of dietary calcium and nonphytate phosphorus. Poult. Sci. 82: 92-99.

McDonald, P., R. A. Edward, J. F. G. Greenhalgh dan C. A. Morgan. 2002. Animal Nutrition. Ed ke-6. Longmann Singapore Publishers (Pte) Ltd. Singapore.McLeod, M.G., C. C. Whitehead, H. D. Griffin dan T. R. Jewitt. 1988. Energy and nitrogen retention and loss in broiler chickens genetically selected for leanness and fatness. Br. Poult. Sci. 67: 285-292

Mirnawati, B. Sukamto dan V., D. Yunianto. 2013. Kecernaan protein, retensi nitrogen dan massa protein daging ayam broiler yang diberi ransum daun murbei (Morus alba L) yang difermentasi dengan cairan rumen. JITP 3 (1) : 25-32.

Nasoetion, M.H. 2001. Pengaruh Pemberian Kelenjar Tiroid Sapi Pasca Pembatasan Pakan terhadap Penampilan dan Penggunaan Protein Ayam Broiler. Tesis. Fakultas Peternakan Universitas Diponegoro, Semarang.

Onyango, E. M., R. N Dilger, J. S. Sands and O., Adeola. 2004. Evaluation of microbial phytase in broiler diets 1 . Poult Sci 83 : 962-970.

Saima, M., Z. U. Khan, M. A. Jabbar, A. Mehmud, M. M. Abbas and A. Mahmood. 2010. Effect of lysine supplementation in low protein diets on the performance of growing broilers. Pakistan Vet. J. 30 (1):1720.

Trisiwi, H.F., Zuprizal, dan Supadmo. 2004. Pengaruh level protein dengan koreksi asam amino esensial dalam pakan terhadap penampilan dan 
nitrogen ekskreta ayam kampung. Buletin Peternakan 28 (3): 131 - 141.

Viveros A, A. Brenes, I. Arija and C. Centeno. 2002. Effects of microbial phytase suplementation on mineral utilization and serum enzyme activities in broiler chicks fed different levels of phosphorus. Poult Sci 81:1172-1183.

Wahju, J. 2004. Ilmu Nutrisi Unggas. Gadjah Mada University Press, Yogyakarta.

Yusriani, Y., T. Toharmat, Sumiati, E. Wina and A. Setiyono. 2011. Effect of fermented Jatropha curcas meal combined with enzymes on metabolizable energy, retention of $\mathrm{N}$, $\mathrm{P}, \mathrm{Ca}$ and digesteble crude fiber. JITV 16(3): 163-172. 